\title{
Experimental and numerical investigation of forced convection in a double skin façade by using nodal network approach for Istanbul
}

\author{
Tugba Inan ${ }^{\mathrm{a}, 1}$, Tahsin Basaran ${ }^{\mathrm{b}, *}$ \\ ${ }^{\text {a }}$ Department of Architecture, Nigde Omer Halisdemir University, Nigde 51240, Turkey \\ ${ }^{\mathrm{b}}$ Department of Architecture, Izmir Institute of Technology, Izmir 35430, Turkey
}

\section{A R T I C L E I N F O}

\section{Keywords:}

Double skin façade

Forced convection

Nodal network

Solar radiation

\begin{abstract}
A B S T R A C T
In this study, temperature distribution and heat transfer through the cavity of a double skin façade (DSF) was investigated in the laboratory environment and analyzed numerically by using nodal network approach. The verification of the nodal network method was conducted by using data from the steady-state experiments and the same method was applied for the climate of Istanbul, Turkey under unsteady outside boundary conditions. Furthermore, heat gain and loss values in DSF for January and July were calculated and compared with single skin façade (SSF) application for different directions of the façades. The results were given for a day and a working time period of the office buildings by using monthly average daily climate data. Distinction working hours were more convenient to investigate the energy performance of DSF because of solar radiation effect. Using DSF in all directions, the cooling loads decreased up to $26 \%$ comparing to the SSF. DSF system was disadvantageous comparing to the SSF for January. However, it was shown that the heated air in the cavity could be used for preheating process of air in a HVAC system for winter period.
\end{abstract}

\section{Introduction}

It is possible to see that the use of double skin façade (DSF) applications in buildings globally pervades. The basic presumption behind this global proliferation is that considering the climatic conditions, the DSF can provide the advantages of energy gaining and controlled ventilation. While looking at the architectural configuration concepts, it is important to notice that all types of DSF can be combined with all types of ventilation and airflow concepts (Fig. 1). This condition creates a great variety of double skin façade configurations. It draws attention to the proper combination of the all parameters proposed in the classification. Effective parameters in architectural configuration issues are illustrated in Fig. 1.

The flow and heat transfer analysis through the cavity of DSF have been evaluated on various studies in the literature. More recent reviews of DSF have been compiled in the studies cited (Pomponi et al., 2016; Ghaffarianhoseini et al., 2016; Zhang et al., 2016). There are different experimental and numerical methods and techniques that could be used to examine the energy performance of DSFs in the literature. Some researchers have used nodal network approaches for energy balance in DSF applications. Various ventilated façade designs were investigated in terms of energy savings by using a commercial building simulations code connected to the nodal airflow network in Haase et al. (2009)'s study. The model was validated with the measured data for an office building and emphasized that the amount of heat gain through the building envelope could be reduced significantly by a ventilated DSF cavity. DSF systems on South, Southeast and Southwest were the most efficient orientations for energy savings for hot and humid climates as Hong Kong's. A zonal model approach through the cavity of DSF was developed after validation by using an experimental setup with different airflow rates and angles of the solar shading in Kuznik et al. (2011)'s study.

Although numerical modeling might apply to many cases envisaged, it needs to be validated with experimental data or analytical models before making any judgment based on the result of numerical modeling. It was examined with a different variation of the airflow through the DSF and different angle of the solar shading device in a test cell under controlled environment by Gavan et al. (2010). Analysis showed that the surface and air temperatures were primarily determined by the angle of sun-shading device and secondly by the air flow rate. A lumped model was validated by thermal measurements from double skin façade test cell before calculating yearly building energy demands in Panão et al. (2016)'s study. A linear model which considered solar radiation and the temperature difference between the outdoors and the room was

\footnotetext{
* Corresponding author.

E-mail addresses: tinan@ohu.edu.tr (T. Inan), tahsinbasaran@iyte.edu.tr (T. Basaran).

${ }^{1}$ Permanent address: Tugba Inan was in the Department of Architecture, Izmir Institute of Technology for the current study.
} 


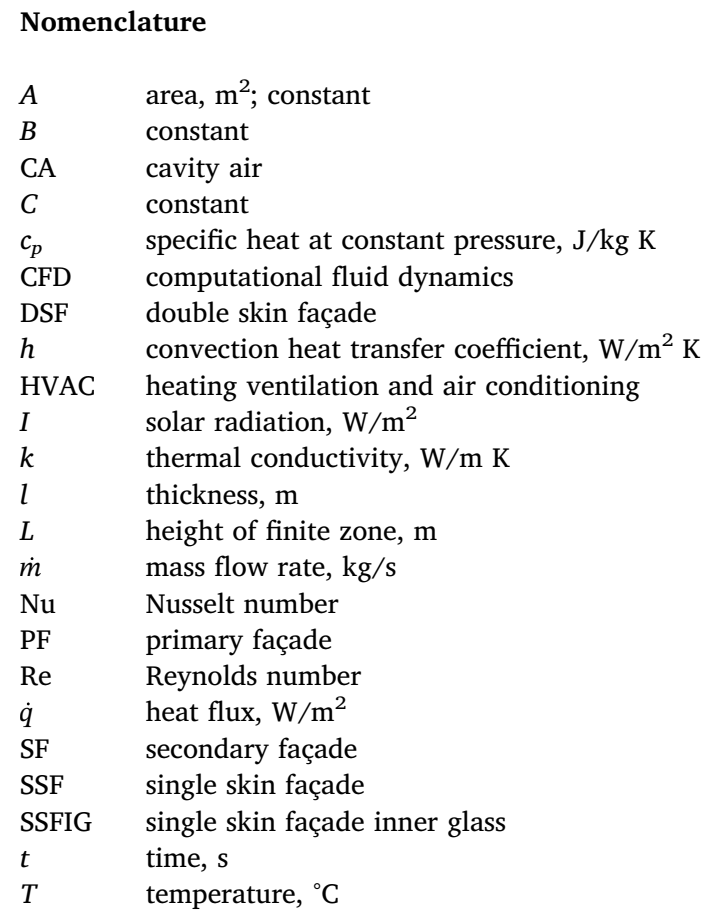

$\begin{array}{ll}U & \text { overall heat transfer coefficient, } \mathrm{W} / \mathrm{m}^{2} \mathrm{~K} \\ V & \text { velocity, } \mathrm{m} / \mathrm{s} \\ y & \text { coordinate axis-along the cavity height } \\ Z & \text { constant }\end{array}$

Greek symbols

$\begin{array}{ll}\alpha & \text { absorptivity } \\ \varepsilon & \text { emissivity } \\ \nu & \text { kinematic viscosity, } \mathrm{m}^{2} / \mathrm{s} \\ \rho & \text { density, } \mathrm{kg} / \mathrm{m}^{3} \\ \sigma & \text { Stephan-Boltzmann constant, } \mathrm{W} / \mathrm{m}^{2} \mathrm{~K}^{4} \\ \tau & \text { transmissivity }\end{array}$

\section{Subscripts}

$\begin{array}{ll}\text { avg } & \text { average } \\ c & \text { cross section } \\ \text { DG } & \text { double glass } \\ \text { ent } & \text { enter } \\ \text { ex } & \text { exit } \\ \text { in } & \text { indoor } \\ h & \text { hydrolic } \\ \text { out } & \text { outdoor } \\ r & \text { radiation }\end{array}$

obtained for evaluating energy performance of DSF by He et al. (2016).

Energy reduction by using DSF was also compared with single skin façade (SSF) in the literature. Cooling loads on a SSF against different physical properties of the outer skin of the DSF was compared and showed that the reflective DSF provided better energy savings (Hamza, 2008). Various configurations including glazing type, glazing position and the usage of double or single skin façade were evaluated considering the energy performance for an office building under the climatic condition of Hong Kong (Chan et al., 2009). They compared to four different glazing position of DSF: the inner and outer façades could be all single or double glazing; and the inner could be single (or double) when the outer was double (or single). After choosing single inner-outer double configuration considering better energy performance, they studied effect of the glazing type as clear, absorptive and reflective glasses. It was obtained that DSF with single clear glazing as inner skin and double reflective glazing on the outer skin provide an annual saving of nearly $26 \%$ in the cooling energy of building, as compared to a conventional single skin façade with single absorptive glazing. Moreover, it was stated that the DSF system was economically infeasible in the long payback period of 81 years (Chan et al., 2009). Different slat angle and operation effect of the blind integrated in the cavity were also investigated on the cooling load reduction by Lee et al. (2013). It was obtained that the greatest reduction of the cooling load could be acquired by the cavity operation, followed by the blind operation and proper choice of the blinds operating hours. The difference between box window type DSF and SSF were compered by Nătase et al. (2016) considering the heat transfer mechanism by using one-year chart for climatic condition in Romania. Finding energy-saving solutions for an existing high rise office building envelopes in Netherlands as a temperate climate considering glazing type, window-to-wall ratio and sun shading was the aim of Raji et al. (2016)'s study. A significant energysaving by around $42 \%$ for total energy use was calculated after the optimization of the parameters.

This study distinguishes itself with different boundary conditions in the laboratory environment with the climate of Istanbul and the specific geometric features of DSF application. Inner façade was chosen as a clear double glazing when the outer was single clear glazing in this study like common practice of DSF (Chan et al., 2009; Eicker, 2003). On the other hand, the opposite configuration was also mentioned in the subtropical region like Hong Kong (Chan et al., 2009). Heat transfer values in DSF were calculated and compared with SSF for different orientations of the façades. For that purpose, a nodal network approach was used and validated by the experimental setup in the laboratory environment under the steady-state conditions. Convective heat transfer coefficients at the both cavity's inside surfaces were obtained from the CFD analysis (Inan et al., 2017). The same method was applied for the climate of Istanbul, Turkey under unsteady outside boundary conditions. Same experimental setup was used for analyzing the effect of perforated elements on pressure drop in the DSF's cavity (Başaran and İnan, 2016). Different perforated plates were positioned in the cavity in order to create a pressure drop. After that, perforated plates in the cavity were removed from the system and the experimental setup was reorganized for forced flow condition by using the air cavity designed in the box window type of DSF. So the experimental setup was ready to investigate the temperature distribution and heat transfer through the cavity of the DSF. The first part (Section 2) of the paper describes the experimental study with the data collection from the setup and the data collection for Istanbul climatic condition. Methodology section is about the nodal network calculation method and after validation of the nodal network by using data from the steady-state laboratory experiments; same method is applied for the climate of Istanbul under unsteady outside boundary conditions in the Section 4 . Hence, heating and cooling loads in DSF for Istanbul can be analyzed and compared with SSF application for different working time periods.

\section{Places, instruments and data}

\subsection{Places}

The experimental setup was placed at the Building Physics Laboratory, which is $11.9 \mathrm{~m}$ in width, $17.8 \mathrm{~m}$ in length and $4 \mathrm{~m}$ in height, on the ground floor of Block B of the Faculty of Architecture, Izmir Institute of Technology, Izmir, Turkey. The experimental setup was used for the verification of the nodal network method under steady-state condition. The same nodal network method was applied for the climate of Istanbul, Turkey under unsteady conditions of January and July. 


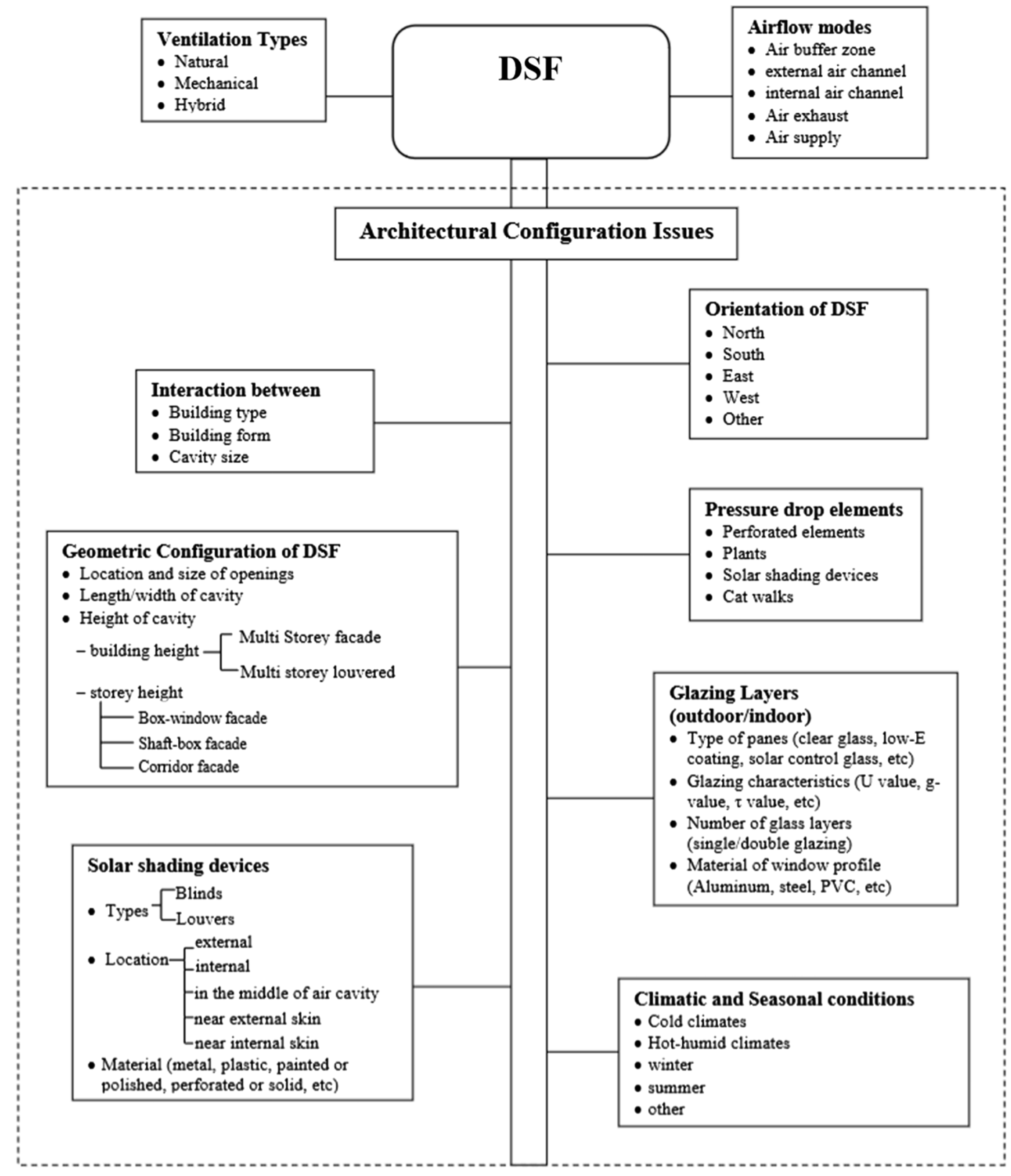

Fig. 1. Effective parameters on Double Skin Façades.

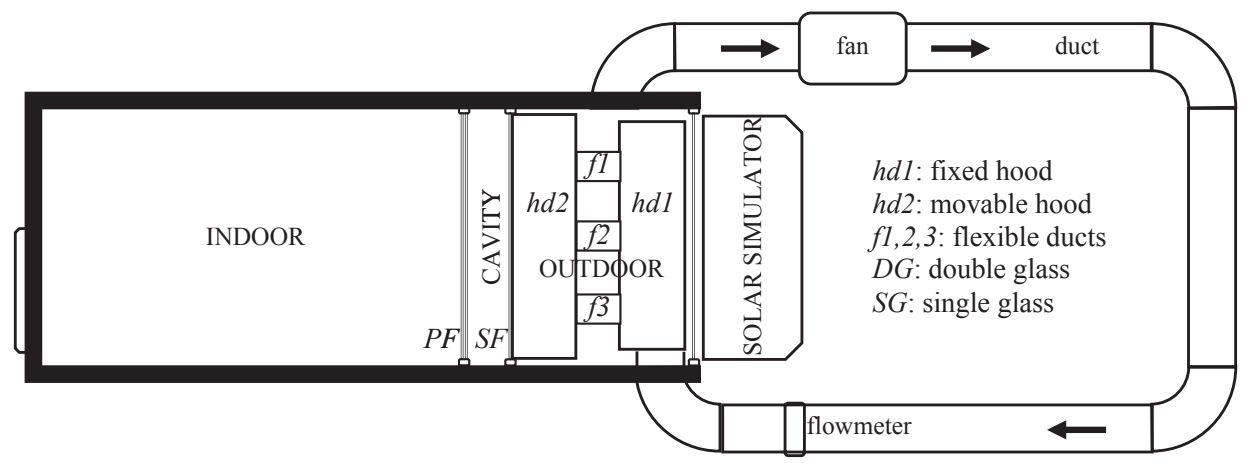

Fig. 2. Experimental setup plan. 


\subsection{Instruments}

General plan of the experimental system was shown in Fig. 2. The system consists of two main parts namely "indoor" and "outdoor" environments with a "cavity" between these two simulated environments. The "indoor" and "outdoor" environments were conditioned by a constant temperature water bath and a refrigeration-based system. The cavity walls were double-glazed (PF) and single-glazed (SF) which separated the "indoor" and "outdoor" environments, respectively. A "fan" was integrated into the "duct" system to create ventilation inside of the cavity by using two openings for air entrance and exit in the singleglazed exterior glass (SF) of the cavity. Air entry to the cavity was performed by two distribution hoods (hd1 and hd2 in Fig. 2). Three flexible ducts $(f 1,2,3)$ were used between these hoods; one of hood (hd2) was mounted on the single exterior glass (SF) and it was movable with the single glass for changing the cavity depth. The other hood (hd1) was connected to the duct system for the air entrance. Moreover, the flow is made as homogeneous as possible by adding a perforated plate at the outlet of the hood2 (Fig. 2). An automatic air-cooled matrix type "solar simulator" was used to provide the required conditions in the experimental study. The whole support structure of the solar simulator was made of aluminum and designed by a modular system which consisted of 12 lamps located to constitute a $3 \times 4$ matrix. Metal halide lamps used in the solar simulator consumed $12 \mathrm{~kW}$ totally (Fig. 2). 4 (at the middle column of the matrix) and 8 (4 lamps at the middle column plus 2 lamps each side of the middle column positioned symmetrically) lamps were used in the experimental parts of this study.

\subsection{Calibration and uncertainty processes of the experimental setup}

Each one of all temperature probes with the data logger were calibrated in the calibration laboratory of Izmir Chamber of Mechanical Engineers (Inan, 2016). The pyranometer system and the velocity measurement system in the duct were used for the first time and calibrated in the manufacturer's laboratory. The uncertainty analysis of air in the cavity was conducted by using each independent property, as density, specific heat, temperature difference, velocity and the cross section area of cavity. Therefore, the uncertainty of the energy transfer rates for air in the cavity were calculated by considering the property as
5.4\% (Başaran and İnan, 2016). The uncertainty of the pyranometer was given as $7.00 \mu \mathrm{V} / \mathrm{Wm}^{-2}$. The pyranometer sensor was also calibrated by using the position difference of the pyranometer measured radiation created by the solar simulator (Fig. $3 a$ ) at $7.2 \mathrm{~cm}$ behind the secondary façade. The pyranometer was located under $55 \mathrm{~cm}$ of the upper glass surface and right at the middle axis after measurements (Fig. 3b). This point reflected the average solar radiation values for the different two cavity depths. This location was considered for 20 measurement points, and the radiation distribution was given for 8-lamp configuration (experiments were also repeated for 4-lamp) as shown in Fig. 3c. Detailed calibration processes and the uncertainty analyses were given in the previous studies (Başaran and İnan, 2016; İnan, 2016).

\subsection{Data collection from the experimental setup under steady-state condition}

Fig. 4 includes the schematic representation of a limited zone of the DSF, in which the experimental and numerical studies have been conducted. Here, PF refers to the primary double skinned glazed façade; SF, to the secondary single glazed façade; and CA, to the air inside of the cavity (Fig. 4). $y$ is the height of the cavity and temperature measurements are recorded for three levels of the height. $T_{\text {ent }}$ shows the temperature of the air which enters the finite zone where the numerical analysis would be conducted, whereas $T_{e x}$ shows the temperature of the air which exits from this finite zone. In this way, depending on the heat transfer in the cavity, the air temperature in the cavity changes. $T_{P F}$ and $T_{S F}$ represent the temperature of the surface of the primary and secondary façades which face the cavity and $T_{P F I G}$ is the inner surface temperature of the primary façade. Furthermore, $T_{i n}$ shows the average indoor temperature of the experiment room, whereas $T_{\text {out }}$ shows the average value of the outdoor environment temperature. $h_{\text {in }}$ and $h_{\text {out }}$ refer to the indoor and outdoor convection heat transfer coefficients and $h_{C A}$ is used for the primary and secondary façade convection heat transfer coefficients which are assumed to be same at each surface. The solar radiation which comes to the system is defined as $I_{\text {solar }}$ and it is assumed to be uniform for each experiment individually. Experimental radiation differences for each measurement arise from the number of lamps and the cavity depths which effect the values since the secondary
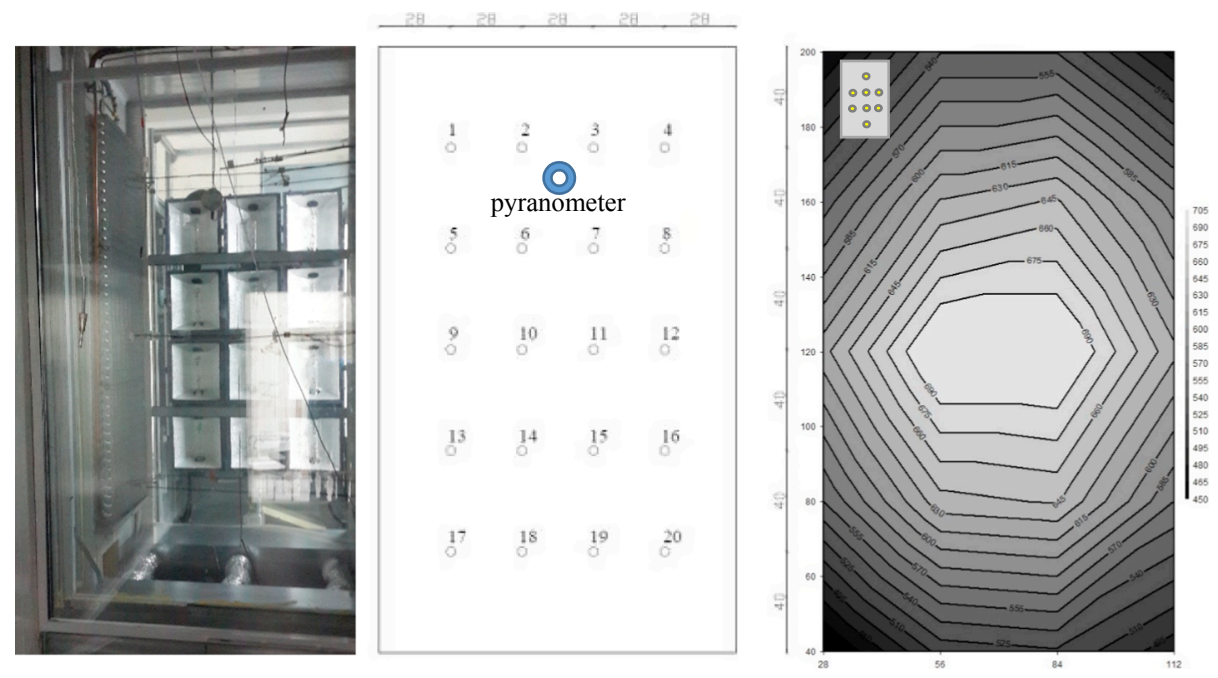

a) Solar simulator view taken from the indoor section

b) Pyranometer position for the experiments (in $\mathrm{cm}$ )

c) Radiation distribution for 8 lamps (in $\mathrm{W} / \mathrm{m}^{2}$ )

Fig. 3. Solar simulator, pyranometer and radiation values. 


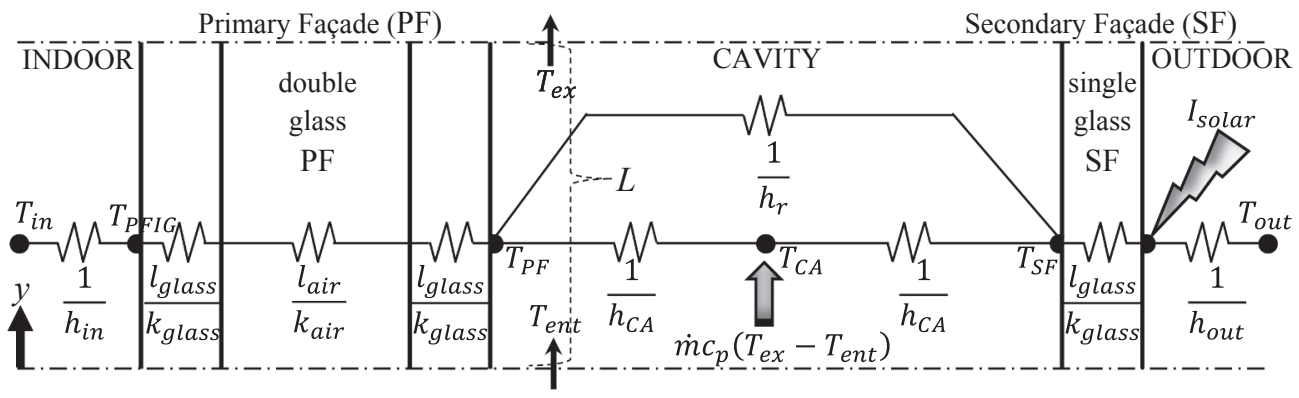

Fig. 4. Schematic view of thermal resistances of the DSF nodal model.

façade's position is changed when the solar simulator is fixed.

Temperature changes of the air in the cavity according to the different cavity depths $(25 \mathrm{~cm}$ and $35 \mathrm{~cm}$ ), different mass flow rates (low, medium and high) and different solar radiation values (between $170 \mathrm{~W} / \mathrm{m}^{2}$ and $365 \mathrm{~W} / \mathrm{m}^{2}$ ) and temperature changes of the primary and secondary façades' surfaces which face the cavity were measured along the height of the cavity mentioned as $y(0.80 \mathrm{~m}, 1.45 \mathrm{~m}$ and $2.10 \mathrm{~m})$ in Table 1 for 12 independent experiments mentioned at the first column. Average values of the indoor temperature (from three measurements), the outdoor environment temperature (from two measurements), air entrance temperature, velocity and solar load were given in Table 1 . These values reflect the average of the measurements taken every $2 \mathrm{~s}$ depending on time after the whole system reached the thermal balance. In the cavity, exterior air curtain flow mode was used. In other words, the air which was taken through the bottom inlet of the double skin façade system was disposed through the top outlet to the outdoor environment. Each calibrated values mentioned as $T_{C A}, T_{P F}$ and $T_{S F}$ in Table 1 were the average values of two temperature measurements at the same height of the cavity. 8 and 4 lamps were opened during the first six-experiments (1-6); and the second six-experiments numbered 7 to 12 , respectively (Fig. 3a). Cavity depth was arranged as $35 \mathrm{~cm}$ (for the experiments numbered $1,2,3$ and $10,11,12$ ) and $25 \mathrm{~cm}$ (for the experiments numbered 4, 5, 6 and 7, 8, 9). Each group included three measurements as 1-3, 4-6, 7-9, and 10-12 had different air mass flow rates namely low, medium and high as shown in Table 1 .

\subsection{Database of the climate of Istanbul}

By using the monthly average daily meteorological data (temperature, wind, solar radiation) of Istanbul province in January (when the outdoor environment average temperature is the lowest) and July (when the outdoor environment average temperature is the highest)

Table 1

Experimental measurement data under steady-state condition.

\begin{tabular}{|c|c|c|c|c|c|c|c|c|c|c|c|c|}
\hline Exp. no & Lamp no & Cavity depth (m) & Mass flow & $I_{\text {solar }}\left(\mathrm{W} / \mathrm{m}^{2}\right)$ & $T_{\text {out }}\left({ }^{\circ} \mathrm{C}\right)$ & $T_{\text {in }}\left({ }^{\circ} \mathrm{C}\right)$ & $T_{\text {inlet }}\left({ }^{\circ} \mathrm{C}\right)$ & $V(\mathrm{~m} / \mathrm{s})$ & Height y (m) & $T_{C A}\left({ }^{\circ} \mathrm{C}\right)$ & $T_{P F}\left({ }^{\circ} \mathrm{C}\right)$ & $T_{S F}\left({ }^{\circ} \mathrm{C}\right)$ \\
\hline \multirow[t]{3}{*}{1} & 8 & 0.35 & low & 365.4 & 27.36 & 24.97 & 17.02 & 0.769 & 0.80 & 18.38 & 22.55 & 26.43 \\
\hline & & & & & & & & & 1.45 & & 25.56 & 27.99 \\
\hline & & & & & & & & & 2.10 & 19.16 & 25.22 & 28.40 \\
\hline \multirow[t]{3}{*}{2} & & & med. & 362.8 & 25.50 & 25.18 & 18.38 & 1.028 & 0.80 & 19.23 & 22.40 & 25.04 \\
\hline & & & & & & & & & 1.45 & & 25.09 & 26.42 \\
\hline & & & & & & & & & 2.10 & 19.77 & 24.62 & 26.97 \\
\hline \multirow[t]{3}{*}{3} & & & high & 364.6 & 22.32 & 25.19 & 18.23 & 1.316 & 0.80 & 18.95 & 21.69 & 23.68 \\
\hline & & & & & & & & & 1.45 & & 24.20 & 24.66 \\
\hline & & & & & & & & & 2.10 & 19.37 & 23.65 & 25.37 \\
\hline \multirow[t]{3}{*}{4} & & 0.25 & low & 330.8 & 26.23 & 23.61 & 17.06 & 1.405 & 0.80 & 18.39 & 20.91 & 24.53 \\
\hline & & & & & & & & & 1.45 & & 23.66 & 25.75 \\
\hline & & & & & & & & & 2.10 & 18.84 & 23.20 & 25.29 \\
\hline \multirow[t]{3}{*}{5} & & & med. & 331.5 & 24.23 & 23.72 & 16.88 & 1.694 & 0.80 & 17.84 & 20.02 & 22.82 \\
\hline & & & & & & & & & 1.45 & & 22.62 & 23.83 \\
\hline & & & & & & & & & 2.10 & 18.20 & 22.10 & 23.58 \\
\hline \multirow[t]{3}{*}{6} & & & high & 334.9 & 22.14 & 23.66 & 17.38 & 2.124 & 0.80 & 18.15 & 19.90 & 22.13 \\
\hline & & & & & & & & & 1.45 & & 22.27 & 22.85 \\
\hline & & & & & & & & & 2.10 & 18.39 & 21.65 & 22.66 \\
\hline \multirow[t]{3}{*}{7} & 4 & 0.25 & low & 170.9 & 14.62 & 26.67 & 8.30 & 1.134 & 0.80 & 8.73 & 12.44 & 12.31 \\
\hline & & & & & & & & & 1.45 & & 15.33 & 13.79 \\
\hline & & & & & & & & & 2.10 & 9.32 & 15.72 & 14.03 \\
\hline \multirow[t]{3}{*}{8} & & & med. & 176.5 & 13.30 & 26.55 & 9.32 & 1.704 & 0.80 & 9.47 & 12.16 & 11.74 \\
\hline & & & & & & & & & 1.45 & & 14.74 & 12.85 \\
\hline & & & & & & & & & 2.10 & 9.83 & 14.97 & 13.09 \\
\hline \multirow[t]{3}{*}{9} & & & high & 178.7 & 11.88 & 26.28 & 9.85 & 2.156 & 0.80 & 9.85 & 12.07 & 11.51 \\
\hline & & & & & & & & & 1.45 & & 14.43 & 12.28 \\
\hline & & & & & & & & & 2.10 & 10.11 & 14.51 & 12.55 \\
\hline \multirow[t]{3}{*}{10} & & 0.35 & low & 196.8 & 16.39 & 28.28 & 10.13 & 0.690 & 0.80 & 10.47 & 15.11 & 14.88 \\
\hline & & & & & & & & & 1.45 & & 17.99 & 16.39 \\
\hline & & & & & & & & & 2.10 & 11.14 & 18.48 & 16.92 \\
\hline \multirow[t]{3}{*}{11} & & & med. & 192.4 & 15.44 & 28.26 & 11.41 & 0.908 & 0.80 & 11.54 & 15.09 & 14.51 \\
\hline & & & & & & & & & 1.45 & & 17.65 & 15.65 \\
\hline & & & & & & & & & 2.10 & 11.98 & 17.94 & 16.19 \\
\hline \multirow[t]{3}{*}{12} & & & high & 196.8 & 12.90 & 28.00 & 11.38 & 1.170 & 0.80 & 11.46 & 14.44 & 13.52 \\
\hline & & & & & & & & & 1.45 & & 16.79 & 14.27 \\
\hline & & & & & & & & & 2.10 & 11.80 & 16.98 & 14.92 \\
\hline
\end{tabular}


depending on the placement of the double skin façade on the all cardinal points and intercardinal points, its energy performance was given. Solar radiation and outside temperature values were taken from the CMSAF (re.jrc.ec.europa.eu/pvgis/apps4/pvest.php) and general directorate of Turkish State Meteorological Service (www.mgm.gov.tr) references as monthly average daily solar radiation and outside temperature values for January and July.

\section{Methodology}

For the DSF in Fig. 4, nodal energy analysis was conducted. DSF was examined by dividing into three main zones which were primary façade (PF), secondary façade (SF) and cavity air (CA). Nodal network is a mathematical approach to define and to model a physical problem. Three zones of the DSF can be set up easily and solved quickly by using this nodal approach. Energy balance was set up for these nodes. Energy balance for the SF is given in Eq. (1),

$I_{\text {solar }} \propto_{S F}=U_{S F}\left(T_{S F}-T_{\text {out }}\right)+h_{C A}\left(T_{S F}-T_{C A}\right)+h_{r}\left(T_{S F}-T_{P F}\right)$

where $h_{r}$ shows the radiant heat transfer coefficient which is used to define the thermal radiation on the facing surfaces of the primary and secondary façades. For the CA, energy balance is defined in Eq. (2).

$\dot{m} c_{p} \frac{d T_{C A}}{d y}=h_{C A} L\left(T_{P F}-T_{C A}\right)+h_{C A} L\left(T_{S F}-T_{C A}\right)$

Eq. (3) is written for the energy balance of the PF.

$I_{\text {solar }} \tau_{S F} \propto_{P F}=U_{P F}\left(T_{P F}-T_{i n}\right)+h_{C A}\left(T_{P F}-T_{C A}\right)+h_{r}\left(T_{P F}-T_{S F}\right)$

With the solution of this equation set (Eqs. (1)-(3)) with three unknowns together with the change in the air temperature in the cavity, the temperature values of the interior surfaces of the DSF which faced the cavity were calculated along the height of finite zone $(L)$ of the cavity in $y$-direction. For this solution, firstly, interior surface temperatures of DSF depending on the cavity air temperature are shown in Eqs. (4) and (5) modified from the reference (Eicker, 2003).

$T_{S F}(y)=\frac{\left(B \propto_{S F}+h_{r} \tau_{S F} \propto_{P F}\right) I_{\text {solar }}+h_{r} U_{P F} T_{\text {in }}+B U_{S F} T_{o u t}\left(B h_{C A}+h_{r} h_{C A}\right) T_{C A}(y)}{A B-h_{r}{ }^{2}}$

$T_{P F}(y)=\frac{\left(A \tau_{S F} \propto_{P F}+h_{r} \propto_{S F}\right) I_{\text {Solar }}+A U_{P F} T_{i n}+h_{r} U_{S F} T_{o u t}+\left(A h_{C A}+h_{r} h_{C A}\right) T_{C A}(y)}{A B-h_{r}{ }^{2}}$

Eqs. (4) and (5) were used to describe $T_{P F}$ and $T_{S F}$ as a function of cavity air temperature, $T_{C A}$. In order to calculate $T_{P F}$ and $T_{S F}$ values along the height of the cavity, first, the change in $T_{C A}$ along the height of the cavity was solved depending on the separation of the variables (Eicker, 2003). The result is given in Eq. (6),

$T_{C A}(y)=\left(1-e^{-Z y}\right) \frac{C_{1} T_{i n}+C_{2} T_{\text {out }}+C_{3} I_{\text {solar }}}{C_{4}}+T_{\text {ent }} e^{-Z y}$

where $C_{1}, C_{2}, C_{3}$ and $C_{4}$ values and the parameter $Z$ were defined by Eqs. (7)-(11), respectively (Eicker, 2003),

$C_{1}=\frac{h_{C A} h_{r} U_{P F}+h_{C A} A U_{P F}}{A B-h_{r}^{2}}$

$C_{2}=\frac{h_{C A} h_{r} U_{S F}+h_{C A} B U_{S F}}{A B-h_{r}^{2}}$

$C_{3}=\frac{h_{C A} h_{r} \tau_{S F} \propto_{P F}+h_{C A} B \propto_{S F}+h_{C A} h_{r} \propto_{S F}+h_{C A} A \tau_{S F} \propto_{P F}}{A B-h_{r}^{2}}$

$C_{4}=2 h_{C A}-\frac{\left(2 h_{C A}^{2} h_{r}+h_{C A}^{2} B+h_{C A}^{2} A\right)}{A B-h_{r}^{2}}$

$Z=\frac{C_{4}}{c_{p} \dot{m}}$ where $A$ and $B$ were defined in Eqs. (12) and (13) as below.

$A=U_{S F}+h_{C A}+h_{r}$

$B=U_{P F}+h_{C A}+h_{r}$

The coefficients $C_{1}$ to $C_{4}$ were related to the convective heat transfer coefficient and the thermal radiation in the cavity, and the overall heat transfer coefficient to the indoor and to the outdoor surfaces. Solar radiation values and the radiation properties of both of these glasses were also used in calculating these values $\left(C_{1}\right.$ to $\left.C_{4}\right)$. As these coefficients were temperature dependent, $T_{P F}, T_{S F}$ and $T_{C A}$ were determined iteratively. Fig. 4 includes the nodal representation of the DSF and it was used in the calculations of the equations given in Eqs. (1)-(3). The parameters and the thermophysical properties which were used here were defined in detail respectively below.

\subsection{Parameter calculations of the secondary façade}

Related values given in Eq. (1) are given in Table 1. The absorption coefficient $\left(\alpha_{S F}\right)$ was accepted as 0.12 ; and the thermal conductivity coefficient of the glass ( $k_{\text {glass }}$ ) was taken as $0.92 \mathrm{~W} / \mathrm{m} \mathrm{K}$ (Çengel, 2007). The value of outdoor convective heat transfer coefficient $\left(h_{\text {out }}\right)$ was calculated depending on the velocity as it is given in Eq. (14) (Liu and Harris, 2007).

$h_{\text {out }}=7.42 V_{\text {out }}+2.98$

Velocity value was calculated by using cavity air mass flowrate and the cross section area of the outside environment of the experimental room. In this way, the value of the modified overall heat transfer coefficient of the secondary façade, $U_{S F}$ is calculated in Eq. (15).

$U_{S F}=\left(\frac{l_{\text {glass }}}{k_{\text {glass }}}+\frac{1}{h_{\text {out }}}\right)^{-1}$

In calculating the secondary façade convective heat transfer coefficient, $h_{C A}$, the Eq. (1) which was acquired as a result of the CFD analyses in the previous study (İnan et al., 2017) was used in Eq. (16).

$N u=0.1338 R e^{0.6844}$

Nusselt and Reynolds numbers were calculated by using Eqs. (17) and (18), respectively.

$N u=\frac{h_{C A} D_{h}}{k_{\text {air }}}$

$R e=\frac{V D_{h}}{v}$

By using the mass flow rate which was experimentally measured, the average velocity value, $V$ was calculated by using Eq. (19),

$\dot{m}=\rho A_{c} V$

where the change of the density $(\rho)$ of air like the kinematic viscosity $(\nu)$ and the thermal conductivity $\left(k_{\text {air }}\right)$ depending on the temperature were considered. Hydraulic diameter, $D_{h}$ was calculated by using cross section area and the perimeter of the cavity. So, the convective heat transfer coefficient, $h_{C A}$ which was assumed to be equal to each surface of the cavity was obtained by using Eqs. (16)-(19).

To calculate the radiative heat transfer coefficient, $h_{r}$ the following equation below was used (Saadon et al., 2016). Emissivity coefficient of both primary façade (PF) and secondary façade (SF) were equal to 0.9. Temperature values were given in K in Eq. (20), and $\sigma$ was the StephanBoltzmann constant given as $5.67 \mathrm{E}-08 \mathrm{~W} / \mathrm{m}^{2} \mathrm{~K}^{4}$ (Çengel, 2007).

$h_{r}=4 \sigma\left(\frac{T_{P F}+T_{S F}}{2}\right)^{3}\left(\frac{1}{\frac{1}{\varepsilon_{P F}}+\frac{1}{\varepsilon_{S F}}}\right)$ 


\subsection{Energy balance of the cavity air}

In Eq. (2), the equation of the cavity energy balance, the $y$ direction showed the height of the cavity. Accordingly, the value of $\frac{d T_{\text {air }}}{d y}$ gave the temperature change of the air of the cavity along the height of the cavity, $y . c_{p}$ was the specific heat of air and it was defined depending on the change in the temperature of the air. The average convection heat transfer coefficient for the interior surface of the cavity on the PF was regarded as equal with the other interior surface of the cavity on the SF.

\subsection{Parameter calculations of the primary façade}

The transmissivity coefficient $\left(\tau_{S F}\right)$ which was expressed in the Eq. (3) was accepted as 0.83 and the value of the absorption coefficient $\left(\alpha_{P F}\right)$ as 0.22 (Çengel, 2007). For PF, the modified overall heat transfer coefficient is given in Eq. (21).

$U_{P F}=\left[\frac{1}{h_{\text {in }}}+\left(2 \frac{l_{\text {glass }}}{k_{\text {glass }}}\right)+\frac{l_{\text {air }}}{k_{\text {air }}}\right]^{-1}$

In the calculation of $h_{i n}$, experimental data were used. Accordingly, the energy balance for the double glass was conducted in Eq. (22),

$U_{D G}\left(T_{P F I G}-T_{P F}\right)=h_{\text {in }}\left(T_{P F I G}-T_{i n}\right)$

where $T_{P F I G}$ was the inner surface temperature of the primary façade, $U_{D G}$ was the overall heat transfer coefficient of the double glass and it was calculated as in Eq. (23),

$U_{D G}=\left(2 \frac{l_{\text {glass }}}{k_{\text {glass }}}+\frac{l_{\text {air }}}{k_{\text {air }}}\right)^{-1}$

where the change of $k_{\text {air }}$ depending on the temperature was also considered. All the numerical analysis of the experimental data mentioned above were done under steady-state conditions. The values which were acquired by using all these equations are given together with the other values below in Table 2 .

\section{Results and discussion}

\subsection{Experimental results under steady-state condition and the model validation}

Together with the change in the temperature of the air, along the cavity on the surfaces of the primary façade (PF) and secondary façade (SF) which faced the cavity, the comparisons of the values of the temperature which were calculated by using the nodal network model with the experimental measurement results were shown for the different working conditions (Fig. 5). It was seen that the air temperature in the cavity at two points which were acquired from the experimental measurement results (mentioned $\mathrm{M}$ ) were very coherent with the numerical results (mentioned $\mathrm{N}$ ) which are shown with solid lines in Fig. 5. When the surface temperatures were compared depending on the experimental measurement and nodal network results, it was seen that the temperatures were also very coherent with the measurements in the middle of the glass surfaces. However, it was seen that the model behaved more incompatibly with the measurements at the bottom where the measurements were also taken as the air temperature measurements in this zone were taken in a zone which was relatively closer to the air inlets. This difference in the entrance zone occurred due to the fact that the flow was not fully developed yet and was affected by the entrance conditions. Therefore, heat transfer calculations were conducted by taking half meters of intervals from the bottom and top of this point based on the measurements in the middle zone. On the other hand, the main reason of this difference was the nonhomogeneous behavior of the solar simulator having relatively extensive standard deviation as mentioned in the experimental study section. Solar radiation effected relatively low at the upper part of the DSF.

In Fig. 5a and b, numerical and experimental results for high mass flow rate when the cavity were $35 \mathrm{~cm}$ and $25 \mathrm{~cm}$ could be seen, respectively. In these experiments, 8 lamps of the solar simulator were left open and these experiments which were coded as the numbers of 3 in Fig. 5a; and 6 in Fig. 5b are seen, respectively in Table 1. Similar behavior was also observed in the other experiments numbered 1, 2, 4 and 5 for the 8-lamp configuration.

When the cavity was $25 \mathrm{~cm}$ and $35 \mathrm{~cm}$; and 4 lamps of solar simulator were left open; the numerical and experimental results for three different mass flow rates numbered respectively 7 to 12 in Table 1 were also calculated and the results were also coherent with each other (experimental measurements and the nodal model) similar results shown in Fig. 5 (İnan, 2016).

\subsection{Unsteady study for Istanbul climate}

After validation, time dependent analysis was studied for Istanbul climate of Turkey. Using all of the parameters in the nodal network model which was prepared for the steady-state condition, the nodal network model for the monthly average daily climate data for Istanbul province was operated again. The interior environment temperature for January was accepted as $20^{\circ} \mathrm{C}$ and for July as $24^{\circ} \mathrm{C}$. By using the similar value intervals in the previous steady-state numerical model, the value of the mass flow rate was accepted as $0.5 \mathrm{~kg} / \mathrm{s}$ and the cavity width as $30 \mathrm{~cm}$. January and July's solar radiation that reaches building vertical surfaces at the different orientations, were also similar values in the previous steady model except East and West orientation for July. Different from the steady-state numerical model explained previous section, for Istanbul example, for the all of the nodal network models, the indoor surface convection heat transfer coefficient was taken as 1/ $0.13 \mathrm{~W} / \mathrm{m}^{2} \mathrm{~K}$ (Eicker et al., 2008). The value of the outdoor surface convection heat transfer coefficient was calculated as in the Eq. (24) (Liu and Harris, 2007). Here $V_{\text {out }}$ is the value of the wind velocity which is taken from the meteorological data. Eq. (24) is different from the Eq. (14) (Liu and Harris, 2007) because of the wind direction.

$h_{\text {out }}=6.31 V_{\text {out }}+3.32$

The temperature of the entrance to the cavity of the air, $T_{\text {inlet }}$ was considered to be equal to the exterior environment temperature $\left(T_{\text {out }}\right)$ in the nodal network models which were prepared for Istanbul province. In this model, the geometric step of each energy balance volume was arranged as $10 \mathrm{~cm}$. So, the calculated exit temperature of each control volume was the enter temperature of the following volume (Fig. 4). On the other hand, sensible energy storage of the glass material was neglected in the energy analysis applied in every time step. The results of each time step was the initial condition of the previous step. Detail

Table 2

Heat convection and radiation coefficients and related Nusselt and Reynolds numbers.

\begin{tabular}{|c|c|c|c|c|c|c|}
\hline \multirow[t]{2}{*}{ Exp. number } & $h_{\text {out }}$ & $h_{i n}$ & $h_{r}$ & \multirow{2}{*}{$\begin{array}{l}R e \\
-\end{array}$} & \multirow{2}{*}{$\begin{array}{l}\mathrm{Nu} \\
- \\
-\end{array}$} & \multirow{2}{*}{$\begin{array}{l}h_{C A} \\
\left(\mathrm{~W} / \mathrm{m}^{2} \mathrm{~K}\right)\end{array}$} \\
\hline & \multicolumn{3}{|c|}{$\left(\mathrm{W} / \mathrm{m}^{2} \mathrm{~K}\right)$} & & & \\
\hline 1 & 4.75 & 1.34 & 5.01 & 28,991 & 151.7 & 6.69 \\
\hline 2 & 5.35 & 2.19 & 4.96 & 38,576 & 185.4 & 8.21 \\
\hline 3 & 6.01 & 3.97 & 4.89 & 49,481 & 220.9 & 9.76 \\
\hline 4 & 5.29 & 1.98 & 4.90 & 40,009 & 190.2 & 11.12 \\
\hline 5 & 5.77 & 4.21 & 4.83 & 48,400 & 217.5 & 12.70 \\
\hline 6 & 6.48 & 5.07 & 4.80 & 60,605 & 254.8 & 14.89 \\
\hline 7 & 4.85 & 2.79 & 4.42 & 34,252 & 170.5 & 9.68 \\
\hline 8 & 5.79 & 2.83 & 4.38 & 51,288 & 226.6 & 12.80 \\
\hline 9 & 6.53 & 2.81 & 4.36 & 64,756 & 267.0 & 15.20 \\
\hline 10 & 4.57 & 2.77 & 4.54 & 27,301 & 145.4 & 6.26 \\
\hline 11 & 5.07 & 2.82 & 4.52 & 35,728 & 175.7 & 7.59 \\
\hline 12 & 5.68 & 2.86 & 4.46 & 46,069 & 210.1 & 9.08 \\
\hline
\end{tabular}




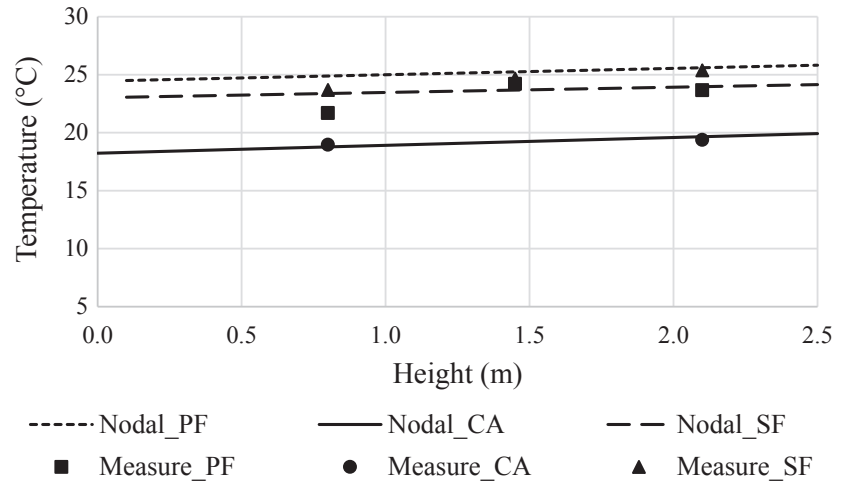

a) Temperature values $\left({ }^{\circ} \mathrm{C}\right)$ for the experiment numbered 3 (8-lamp open, cavity: $35 \mathrm{~cm}$ )

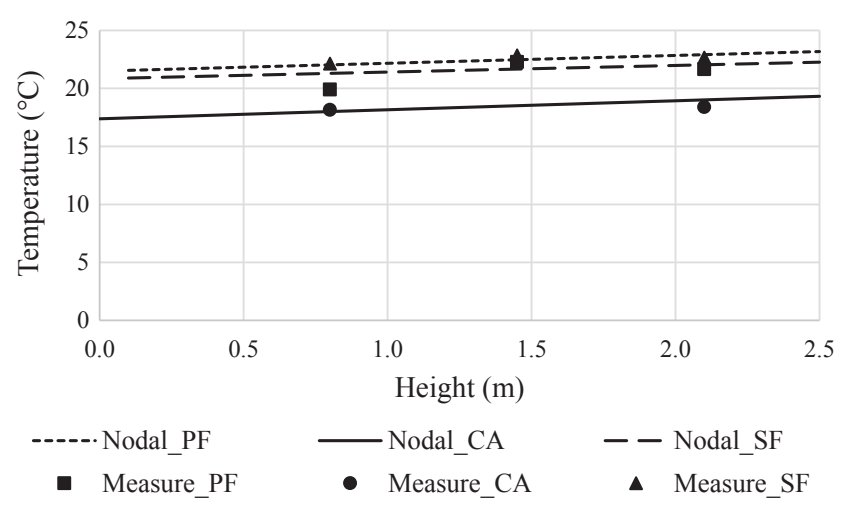

b) Temperature values $\left({ }^{\circ} \mathrm{C}\right)$ for the experiment numbered 3 (8-lamp open, cavity: $35 \mathrm{~cm}$ )

Fig. 5. Temperatures $\left({ }^{\circ} \mathrm{C}\right)$ by the measurements and the nodal model for the high flow rate experiments.

calculation steps with all parameters were defined in the flow chart as shown in Appendix A.

In Fig. 6, temperature distribution was given for South (S) (Fig. 6a) and North (N) (Fig. 6b) façades at 12 am from the time dependent analysis by using monthly average daily data on January for Istanbul. As it was seen in Fig. 7a, South façade had more heat gains due to the solar radiation effects and relatively higher temperature differences occurring between the surfaces (Fig. 6a). Energy level of the air in the DSF cavity increased significantly for both direction as seen in Fig. 6. This gained energy should be used for air preheating purposes in a HVAC system.

Using these calculations, to calculate the heat transfer rate per unit area from DSF due to the temperature difference, Eq. (25) was applied. Using unit length in the horizontal section, the values of the heat transfer rate occurred from the unit surface area were given as heat flux in the results.

$\dot{q}=U_{P F}\left(T_{P F}-T_{i n}\right)$

Fig. $7 \mathrm{a}$ and $\mathrm{b}$ were drawn by using monthly average daily data of January and July for Istanbul. As it is seen in Fig. 7a, due to the temperature difference, all day, for each direction, heat loss (heating load) values occurred for the DSF application and since the solar radiation was present during daytime, heat losses from the façades relatively decreased under the constant indoor condition at $20^{\circ} \mathrm{C}$. In July, although the average exterior temperature was below $24^{\circ} \mathrm{C}$ at nighttime, thanks to the DSF application, heat loss/gain do not occur and positive values increase during daytime (Fig. $7 \mathrm{~b}$ ). The heat flux values in the East and West directions formed different curves despite the symmetrical solar radiation effect.
After the heat loss/gain graphics due to the temperature difference, heat gains thanks to the solar radiation effect for the DSF application are given in Fig. 8 by using the monthly average daily data for January (Fig. 8a) and July (Fig. 8b) in Istanbul. Since the South façade is more effective in January for decreasing of heating load; West and East directions are disadvantage façades for the increasing cooling loads for July condition in Istanbul as shown in Fig. 8a and b.

Using DSF and decreased the heat gain from the sun in January in comparison to SSF, the heating load was affected negatively. The DSF also reduced the heat gain of the solar radiation in July and contributed positively to the cooling load. The decrease in the cooling load was significantly larger than the disadvantage of the heating load. Another important result which was acquired in the nodal network energy analysis is that the change of the energy of the air in the DSF cavity. This energy gain in winter can be used for preheating purposes in a HVAC system. In Fig. 9, at the height of the cavity (and considering the width of the unit cavity) the rate of increasing of the energy level of the air is given depending on different directions by using January data of Istanbul. The height of the cavity is $2.5 \mathrm{~m}$ and the air temperature values are chosen at $0.8 \mathrm{~m}$ and $1.8 \mathrm{~m}$ of the cavity height for calculating of the thermal energy gain of the air in the cavity. These air temperature values are given as a solid line in Fig. $6 \mathrm{a}$ and b for South and North directions at 12:00 for Istanbul. The gradient of the cavity air temperature is more than PF and SF temperature gradients (Fig. 6a and b). So, distinguished energy gain rates for air per unit area (height of $1 \mathrm{~m}$ from $0.8 \mathrm{~m}$ to $1.8 \mathrm{~m}$ and width of $1 \mathrm{~m}$ of the cavity) can be determined by using cavity air temperature difference $\left(T_{\text {ex@1.8m }}-T_{\text {ent } @ 0.8 m}\right)$, mass flow rate $(0.5 \mathrm{~kg} / \mathrm{s})$ and specific heat at constant pressure values $\left(1006.16 \mathrm{~J} / \mathrm{kg}{ }^{\circ} \mathrm{C}\right)$ for each time step $(1 \mathrm{~h})$ for monthly average daily data $(24 \mathrm{~h})$ of January in Istanbul (Fig. 9). For these working conditions, these rates of increasing values at the energy rate of the air are at

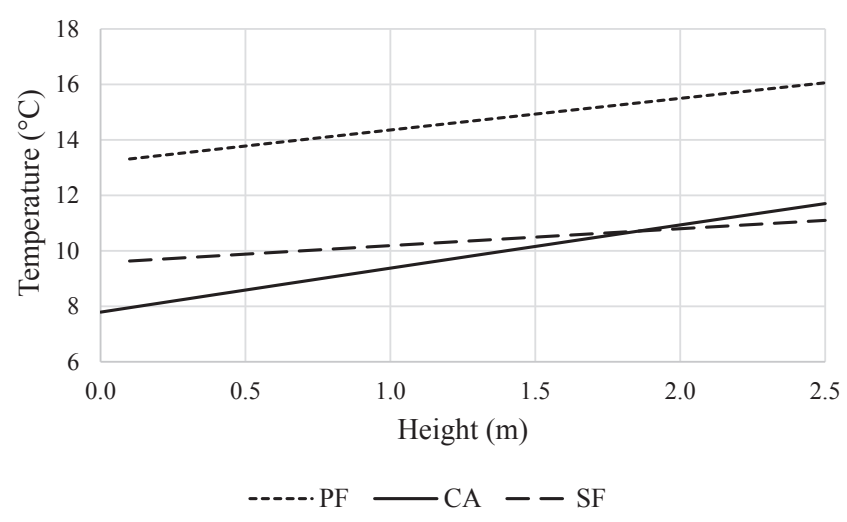

a) South (S) façade

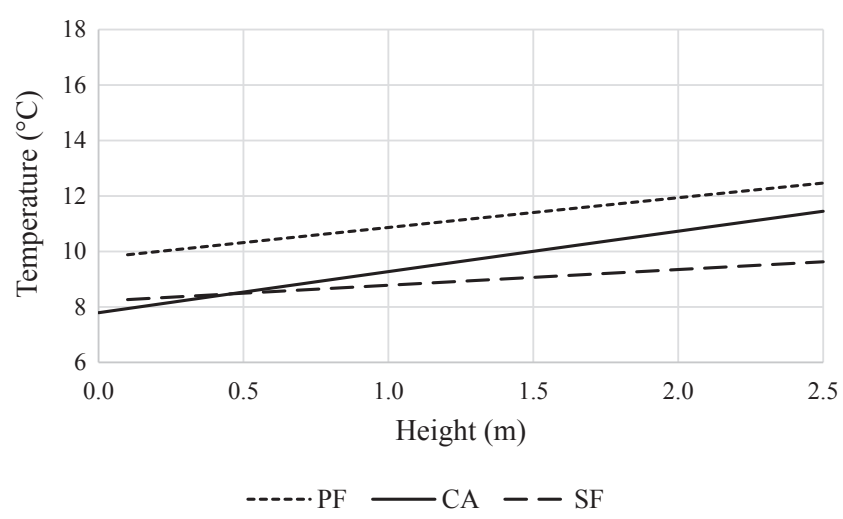

b) North (N) façade

Fig. 6. Temperature $\left({ }^{\circ} \mathrm{C}\right)$ distributions on January at 12 am for Istanbul. 


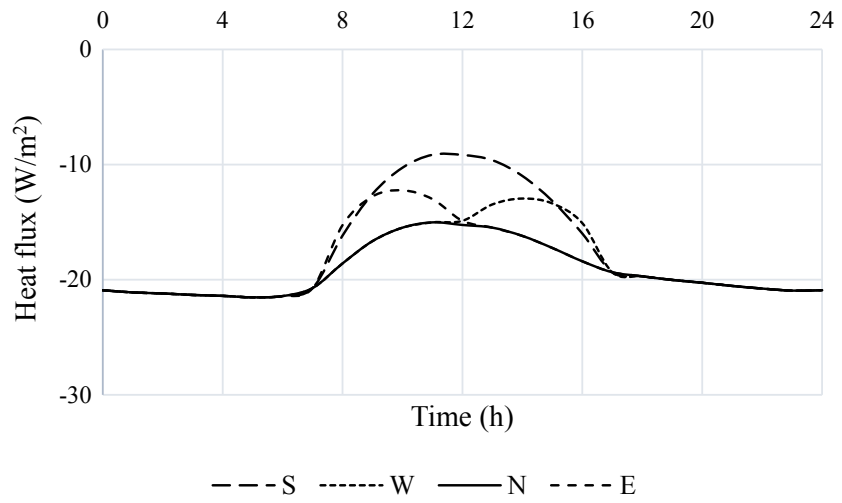

a) Considering monthly average daily climatic data (in $\mathrm{W} / \mathrm{m}^{2}$ ) in January for Istanbul

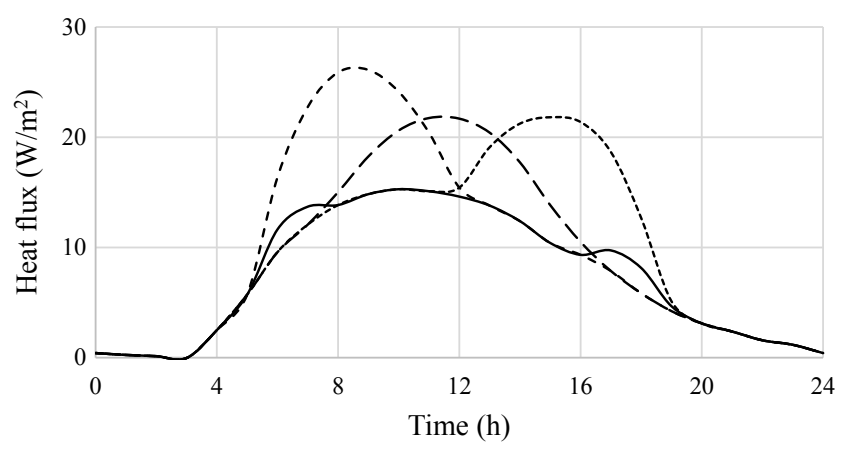

$---\mathrm{S} \quad \cdots-\cdots-\mathrm{W} \longrightarrow \mathrm{N}----\mathrm{E}$

b) Considering monthly average daily climatic data (in $\mathrm{W} / \mathrm{m}^{2}$ ) in July for Istanbul

Fig. 7. Heat transfer rates per unit area (in $\mathrm{W} / \mathrm{m}^{2}$ ) due to temperature difference for DSF.

a significant level when the heat loss-gain values in the previous graphics (Figs. 7 and 8) are considered. Therefore, using this energy in terms of reducing the heating load in winter will provide a significant contribution. The rate of increase at the thermal energy of the air in the DSF cavity on the South façade is higher comparing to the other directions, as it is expected (Fig. 9).

In order to compare DSF with SSF, a similar nodal network approach was also used for SSF. Similarly, the monthly average daily meteorology data for Istanbul were used for SSF. The schematic model of the SSF which was used for comparison and its nodal network illustration is seen in Fig. 10.

According to the nodal network in Fig. 10, the energy balance is given in Eq. (26) below.

$I_{\text {solar }} \propto_{S S F}=U_{\text {SSF }}\left(T_{\text {SSFIG }}-T_{\text {out }}\right)+h_{\text {in }}\left(T_{\text {SSFIG }}-T_{\text {in }}\right)$

Here the time dependent values of $I_{\text {solar }}$ and $T_{\text {out }}$ for Istanbul were used as monthly average daily solar radiation and outside temperature values for January and July. The value of the $U_{S S F}$ overall heat transfer was calculated in Eq. (27) as below.

$U_{S S F}=\left[\frac{1}{h_{\text {out }}}+\left(2 \frac{L}{k_{\text {glass }}}\right)+\frac{L_{\text {air }}}{k_{\text {air }}}\right]^{-1}$

In this way, using the temperature values $T_{\text {SSFIG }}$ which were acquired from the Eq. (26), the heat flux values due to SSF were calculated by using the Eq. (28).

$\dot{q}=h_{\text {in }}\left(T_{S S F I G}-T_{\text {in }}\right)$

Accordingly, the heat transfer rate per unit area due to the

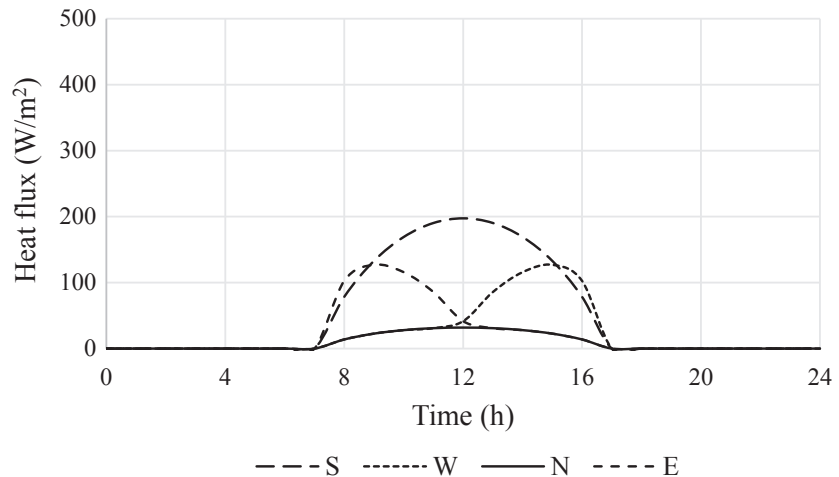

a) Considering monthly average daily data (in $\mathrm{W} / \mathrm{m}^{2}$ ) of January

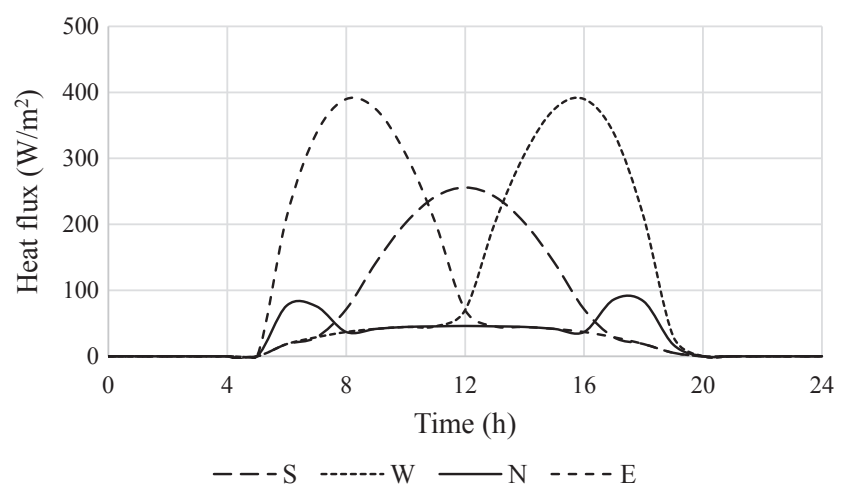

b) Considering monthly average daily data (in $\mathrm{W} / \mathrm{m}^{2}$ ) of July

Fig. 8. Heat gain (in $\mathrm{W} / \mathrm{m}^{2}$ ) from the solar radiation transmitted from DSF in Istanbul for different directions.

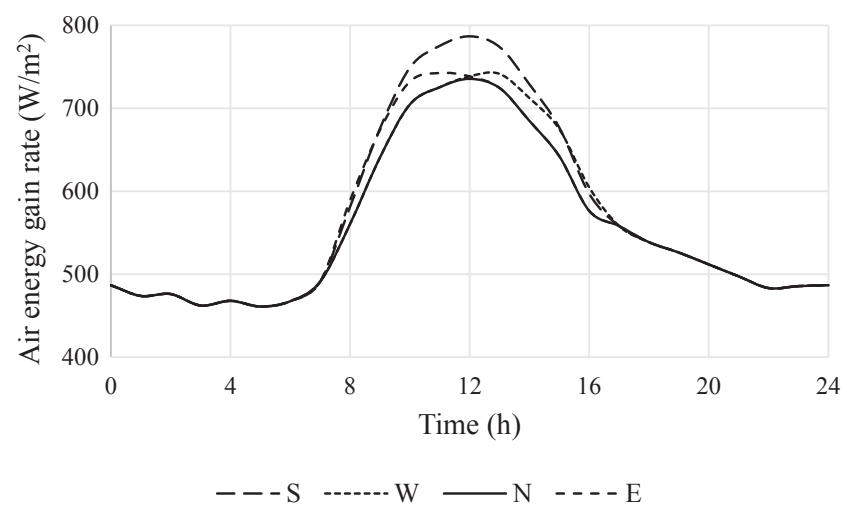

Fig. 9. Air energy gain rate per unit area (in $\mathrm{W} / \mathrm{m}^{2}$ ) of DSF through the cavity by using monthly average daily data of January in Istanbul for different directions.

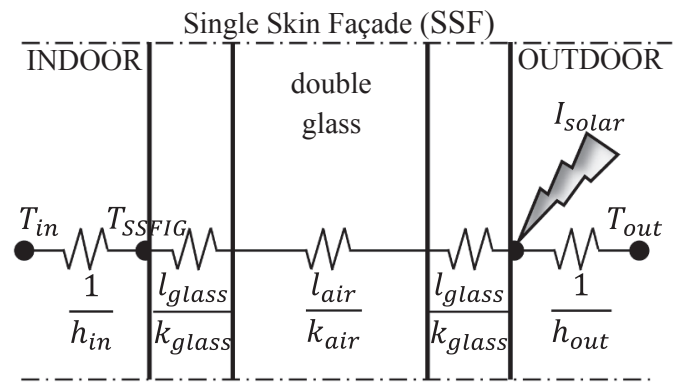

Fig. 10. Schematic view of thermal resistances of the SSF nodal model. 


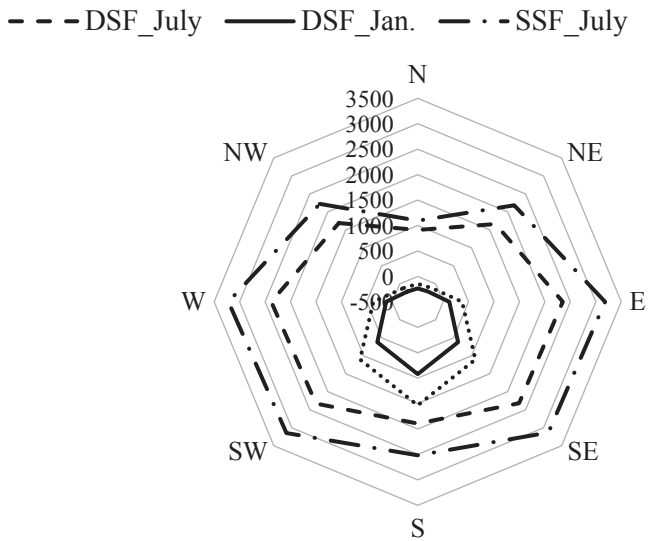

Fig. 11. Heat transfer (in Wh/ $\mathrm{m}^{2}$ day) comparison of DSF and SSF for different orientation and month in Istanbul (for an average day).

temperature difference from SSF were also calculated by using the monthly average daily data for Istanbul for January and July. With the effect of the solar beam which came perpendicular to the glass surface in January, the SSF on the South façade received more thermal energy than the other directions. Heat transfer rate per unit area in July reached very high values with the effect of the solar radiation. Heat gain (cooling load) on the SSF on the East and West façades in July were higher than the other façades as the sun rays come more perpendicular to the surface.

The daily changes in heat transfer rate values, as daily total energy transfer for Istanbul, for January and for July are given in Fig. 11 in the form of $\mathrm{Wh} / \mathrm{m}^{2}$ day by using monthly average daily data of the mentioned months. All day heat transfer values per unit surface areas of DSF and SSF applications are shown in Fig. 11 for four cardinal directions with the four intercardinal directions.

Considering all the directions, it was seen that for the DSF system in which the air flow mode was used, the DSF system offered more advantages than the SSF in July as seen in Fig. 11. The lowest heat gain for July was acquired from the DSF which was located on the North direction as expected because of mainly indirect solar radiation. This advantage was more significant in the South, East, West and their intercardinal directions comparing to the SSF. Using DSF in the North direction, the cooling load decreased $16 \%$ comparing to the SSF; using DSF in the South direction, the cooling load decreased 24\%, and using DSF in both East and West façades, the cooling load decreased $26 \%$. While examining the DSF on the intercardinal points, it was found that comparing to the SSF, for the DSF on the Northeast and Northwest, there was a $23 \%$ decrease in the cooling load, and for the DSF on the Southeast and Southwest, there was a $26 \%$ decrease in the cooling load. These findings were acquired with the nodal model in which the exterior air curtain of the cavity were ventilated with the air flow mode. As there was significant heat gain in the cavity air, it was important that the cavity was ventilated and this gain was disposed out of the cavity.

The double skin façade system in which this exterior air curtain flow mode was used was disadvantageous on all directions comparing to the SSF for January because of the diminished solar radiation. However, this disadvantage which occurred in January was relatively lower comparing to the advantage in July conditions. Only the South direction had similar difference between DSF and SSF in January (614 Wh/ $\mathrm{m}^{2}$ day as a disadvantage value) and in July $\left(624 \mathrm{Wh} / \mathrm{m}^{2}\right.$ day as an advantage value). But, the difference between advantage (837 Wh/ $\mathrm{m}^{2}$ day) and disadvantage ( $252 \mathrm{Wh} / \mathrm{m}^{2}$ day) values increased to $585 \mathrm{Wh}$ / $\mathrm{m}^{2}$ day approximately for the East and West directions as the highest difference because of the relatively higher direct solar radiation effect at the East and West surfaces in July. This difference decreased for the $\mathrm{SE}, \mathrm{SW}, \mathrm{NE}$ and NW directions, and it was only $92 \mathrm{Wh} / \mathrm{m}^{2}$ day for the North direction. In winter period, it was required to use the energy
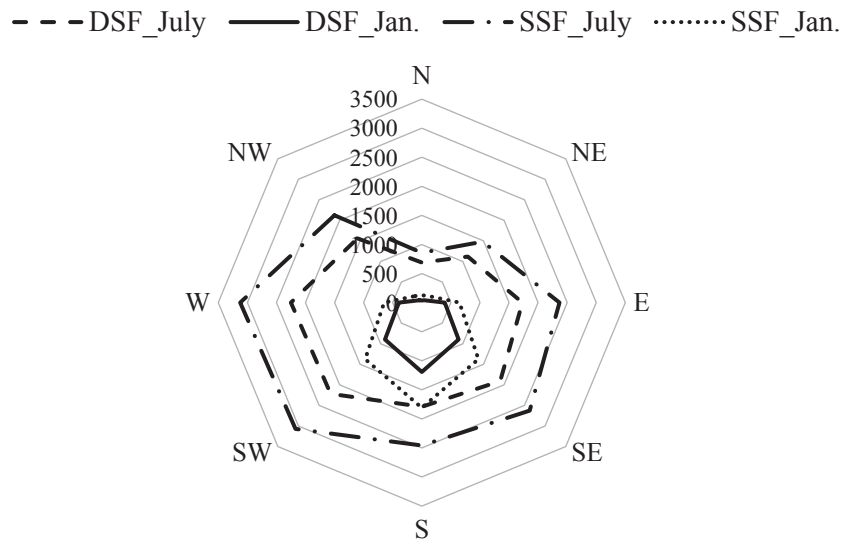

Fig. 12. Heat transfer (in $\mathrm{Wh} / \mathrm{m}^{2}$ day) comparison of DSF and SSF for different orientation and month in Istanbul (for an average day of time period between 8:00 am to $18: 00 \mathrm{pm}$ ).

which was gained from the heated air through the DSF's cavity and related it to a HVAC system for a preheating process.

Daily total heat transfer per unit surface area for a time period between 8:00 am to 18:00 pm was compared with DSF and SSF applications for different orientation by using January and July monthly average daily data are given in Fig. 12. These working hours besides of $24 \mathrm{~h}$ mentioned in Fig. 11 was more convenient to investigate the energy performance of DSF which was generally used in the office buildings. Because of the solar radiation, all heat transfer values were converted to the positive values as seen in Fig. 12. On the other hand, symmetric behavior based on the directions shown in Fig. 11 was changed, because the office working hours was not equally divided as solar hours. Since the July heat transfers were significantly bigger at the East, West, Southeast and Southwest directions due to the solar load at the both two different usages given in Figs. 11 and 12, solar shading devices or different type glass having low transmissivity usage was very important.

\section{Conclusions}

In this study, the nodal network approach which was described by using the results obtained from the experiments was firstly compared for that working conditions. This nodal energy balance approach was used for Istanbul's climatic condition after reaching acceptable results for the external airflow mode in the DSF's cavity. Simplicity of the nodal model with a low computational demand could be a usable tool for designers. Heating and cooling loads in DSF for Istanbul were analyzed and compared with SSF. Convective heat transfer coefficients inside the both cavity surfaces were determined by using the correlation obtained from the CFD analysis.

In general, while the usage of DSF showed unfavorable results rather than SSF in Istanbul for the external airflow mode in the cavity in January, it showed better energy performance in July. A considerable energy gain was observed in the cavity during the airflow. Extracting of this energy to the outside or providing against solar radiation in summer and linking for air preheating in a HVAC system in winter season is significant in terms of energy effectiveness of DSF usage. On the other hand, DSF application was more convenient considering working hours between 8:00 am to $18: 00 \mathrm{pm}$ for office buildings, besides of all day energy performance of SSF for Istanbul climate. Buildings conditioned $24 \mathrm{~h}$ were not appropriate for DSF application comparing the buildings worked daytime. Using solar shading elements at the East, West, Southeast and Southwest orientations of the office buildings with DSF decreased heat gain in summer period due to the solar radiation decrement.

Future research should address the extension of numerical analysis 
to different working conditions such as shading elements, glazing type and climatic data from different locations. All these evaluations should be also included statistical analysis and feasibility estimation for the comparisons.

\section{Declarations of interest}

None.

\section{A. Flow chart}

\section{Acknowledgments}

This work was supported by the Scientific and Technological Research Council of Turkey (TÜBITAK) Foundation under grant number $112 \mathrm{M} 170$.

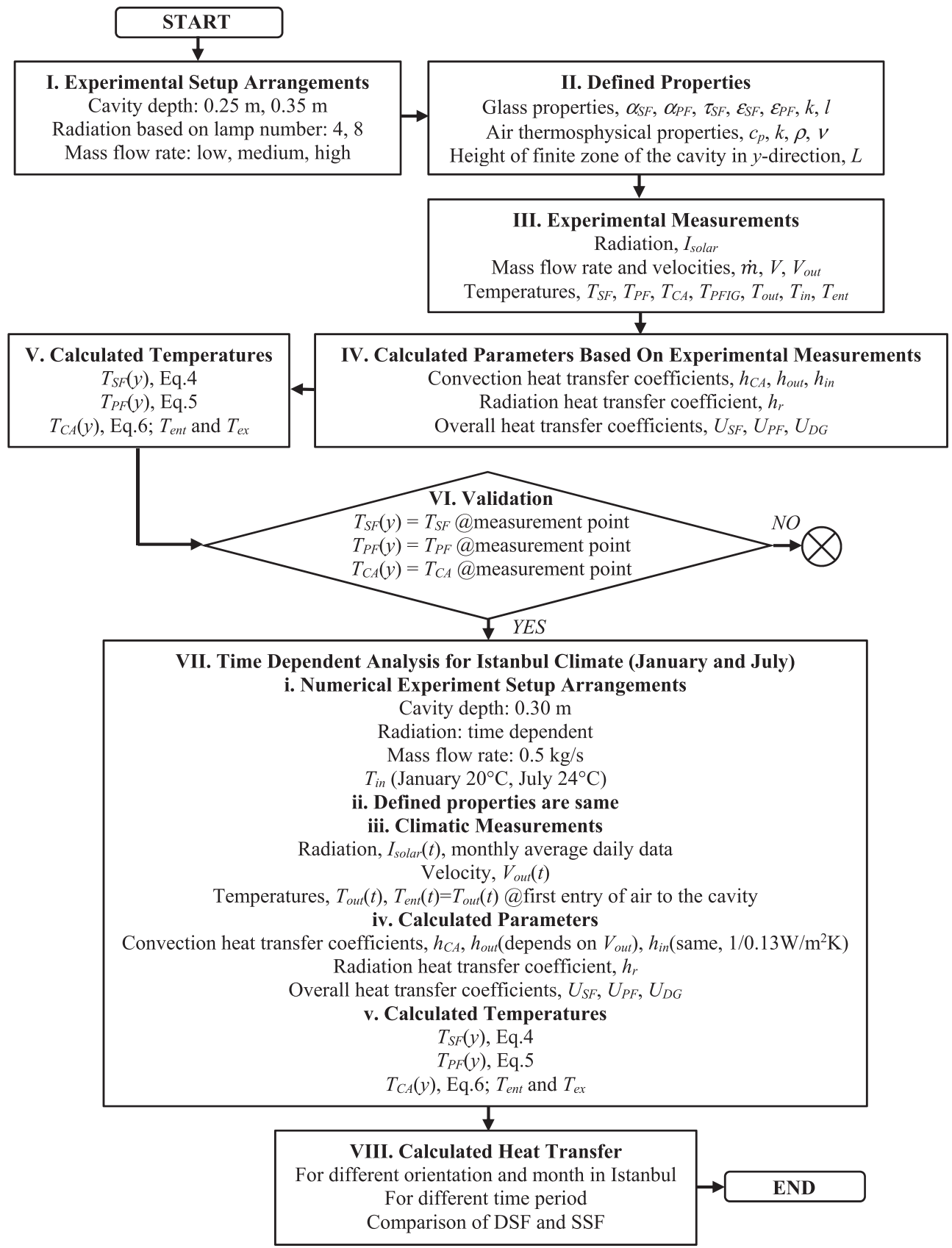

\section{References}

Bașaran, T., İnan, T., 2016. Experimental investigation of the pressure loss through a double skin façade by using perforated plates. Energy Build. 133, 628-639.
Chan, A.L.S., Chow, T.T., Fong, K.F., Lin, Z., 2009. Investigation on energy performance of double skin façade in Hong Kong. Energy Build. 41, 1135-1142.

Cengel, Y.A., 2007. Heat and Mass Transfer, third ed. McGraw-Hill, New York. Eicker, U., 2003. Solar Technologies for Buildings. John Wiley and Sons, West Sussex. Eicker, U., Fux, V., Bauer, U., Mei, D., Infield, D., 2008. Façade and summer performance 
of buildings. Energy Build. 40, 600-611.

Gavan, V., Woloszyn, M., Kuznik, F., Roux, J.J., 2010. Experimental study of a mechanically ventilated double-skin façade with venetian sun-shading device: a fullscale investigation in controlled environment. Solar Energy 84, 183-195.

Ghaffarianhoseini, A., Ghaffarianhoseini, A., Berardi, U., Tookey, J., Li, D.H.W.

Kariminia, S., 2016. Exploring the advantages and challenges of double-skin façades (DSFs). Renew. Sustain. Energy Rev. 60, 1052-1065.

Haase, M., Marques da Silva, F., Amato, A., 2009. A Simulation of ventilated façades in hot and humid climates. Energy Build. 41, 361-373.

Hamza, N., 2008. Double versus single skin façades in hot arid areas. Energy Build. 40, 240-248.

He, G., Xu, J., Zheng, Y., Zhang, S., Bai, Q., 2016. Prediction of solar heat gain of double skin façade windows. Build. Simul. 9, 399-409.

İnan, T., Başaran, T., Erek, A., 2017. Experimental and numerical investigation of forced convection in a double skin façade. Energies 10, 1-15.

İnan, T. 2016. Experimental and Numerical Analysis of Flow and Heat Transfer in Double Skin Façade Cavities. PhD Dissertation. Department of Architecture, Izmir Institute of Technology, Izmir, Turkey.

Kuznik, F., Catalina, T., Gauzere, L., Woloszyn, M., Roux, J.J., 2011. Numerical modelling of combined heat transfers in a double skin façade-Full-scale laboratory experiment validation. Appl. Therm. Eng. 31, 3043-3054.

Lee, K.H., Kim, T., Lee, G., Lee, J., 2013. Cooling load reduction effect and its mechanism in between-glass cavity and venetian blind operation during the summer season. Build. Simul. 6, 351-364.
Liu, Y., Harris, D.J., 2007. Full scale measurements of convective coefficient on external surface of a low-rise building in sheltered conditions. Build. Environ. 42, 2718-2736.

Nătase, G., Şerban, A., Dragomir, G., Bolocan, S., Brezeanu, A.I., 2016. Box window double skin façade. Steady state heat transfer model proposal for energetic audits. Energy Build. 112, 12-20.

Panãoa, M.J.N.O., Santos, C.A.P., Mateus, N.M., Graça, G.C., 2016. Validation of a lumped RC model for thermal simulation of a double skin natural and mechanical ventilated test cell. Energy Build. 121, 92-103.

Pomponi, F., Piroozfar, P.A.E., Southall, R., Ashton, P., Farr, E.R.P., 2016. Energy performance of Double-Skin Façades in temperate climates: a systematic review and meta-analysis. Renew. Sustain. Energy Rev. 54, 1525-1536.

Raji, B., Tenpierek, M.J., Dobbelsteen, A., 2016. An assessment of energy-saving solutions for the envelope design of high-rise buildings in temperate climates: a case study in the Netherlands. Energy Build. 124, 210-221.

Saadon, S., Gaillard, L., Giroux-Julien, G., Menezo, C., 2016. Simulation study of a naturally- ventilated building integrated photovoltaic/thermal (BIPV/T) envelope. Renew. Energy 87, 517-531.

The Satellite Application Facility on Climate Monitoring, CMSAF, < http://re.jrc.ec europa.eu/pvgis/apps4/pvest.php > (accessed 12 May 2016).

Turkish State Meteorological Service, < http://www.mgm.gov.tr/ > (accessed 12 May 2016).

Zhang, T., Tan, Y., Yang, H., Zhang, X., 2016. The application of air layers in building envelopes: a review. Appl. Energy 165, 707-734. 